\title{
RESEARCH OF APPLYING ISF TECHNOLOGY ON PVC PLASTIC SHEET TO MANUFACTURING SOME NORMAL PRODUCTS
}

\author{
Nguyen Van Nang ${ }^{(1)}$, Nguyen Thanh Nam ${ }^{(1)}$, Le Khanh Dien ${ }^{(2)}$, Nguyen Thien Binh ${ }^{(1)}$, Nguyen \\ $\operatorname{Minh} \mathbf{T u}^{(1)}$ \\ (1) National key Lab. of Digital Control and System Engineering \\ (2) The Faculty of Mechanical Engineering, HCM city University of Technology \\ (Manuscript Received on April $5^{\text {th }}, 2012$, Manuscript Revised November 20 ${ }^{\text {rd }}, 2012$ )
}

ABSTRACTS: Market demand is always changing over time especially for plastic products. Therefore it is necessary to create sample models in the meaning of single or small-batch production which is expected with short processing time, lower cost and operating simply but also meet the technical requirement. This paper presents a research of applying ISF process on PVC plastic sheet to manufacturing sample models and small-batch products. There is also a comparison of economic efficiency between ISF technology and traditional plastic forming methods.

Keyword: Appling ISF technology, ISF process, manufacturing PVC civil products.

\section{INTRODUTION}

Polymer is a popular material in social life since the fact that there are many products made from plastic material. Tranditional technology to manufacture polymer products almost follows the three steps: heating forming - cooling in which polymer material is operated on yield or plastic status. This method is only suitable for mass production because of high cost for energy and equipment. Therefore it is necessary to have some new flexible technologies which not only applies the requirement of economic efficiency but is also suitable for small batch production and rapid prototyping.
New sheeting forming technology has been developed recently (Incremental Sheeting Forming (ISF) technology. Two types of ISF are Single Point Incremental Forming (SPIF) and Two Point Incremental Forming (TPIF). As the beginning only sheet metal is applied for ISF technology, it has been processed for plastic material recently since the wide usage of polymer and composite products in social life. ISF process uses fixture on which blank sheet is clamped between single frames. During ISF process toolpath is controlled by $\mathrm{CNC}$ machine or industrial robot. By that way, forming tool movement follows product boundary slide-by-slide and blank sheet is formed gradually. (Fig 1.) 


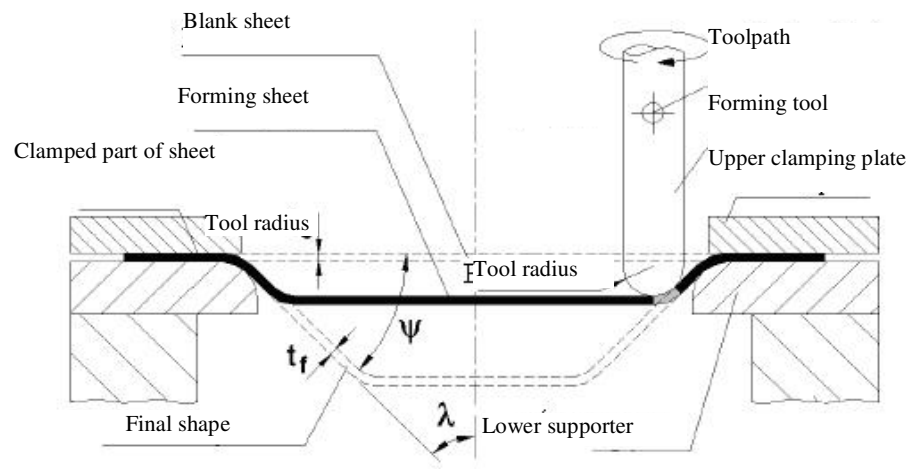

Fig.1. Fixture and other equipments in ISF process - SPIF type.

Market demand is always changing over time especially for plastic products. Therefore it is necessary to create sample models in the meaning of single or small-batch production which is expected with short processing time, lower cost and operating simply but also meet the technical requirement. This paper presents a research of applying ISF process on PVC plastic sheet to manufacturing sample models and small-batch products. There is also a comparison of economic efficiency between ISF technology and traditional plastic forming methods.

\section{ISF PROCESS ON PVC PLASTIC SHEET}

ISF process on PVC plastic sheet is similar with processing on sheet metal while forming tool move around a preset orbit controlled by a CNC machine to deform sheet blank. The underformed sheet blank is clamp by clamping plates attached on table machine. Formed parts and tool path is built form the CAD/CAM model [5] (fig.2.). All the basic contents of ISF process (SPIF type) is presented in fig.3. [6].

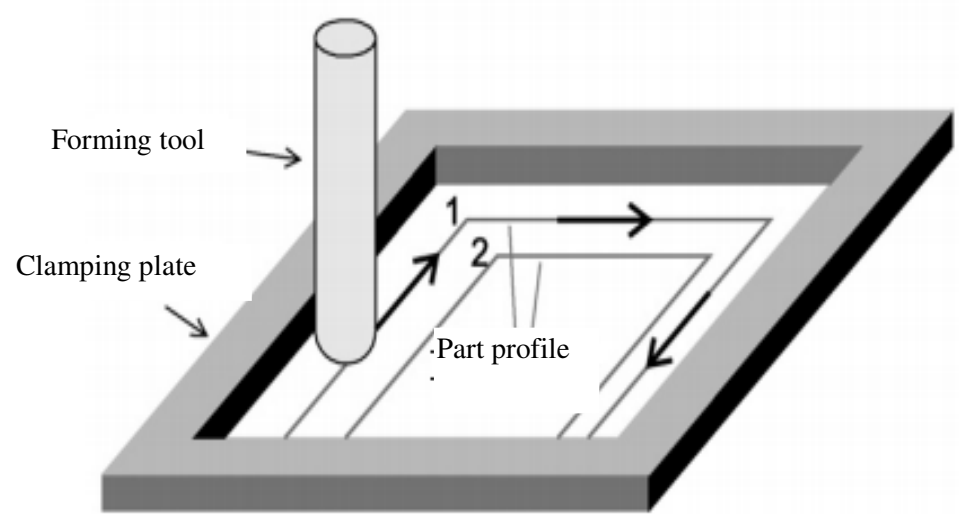

Fig.2. CAD model and tool path of ISF process

\section{Trang 16}




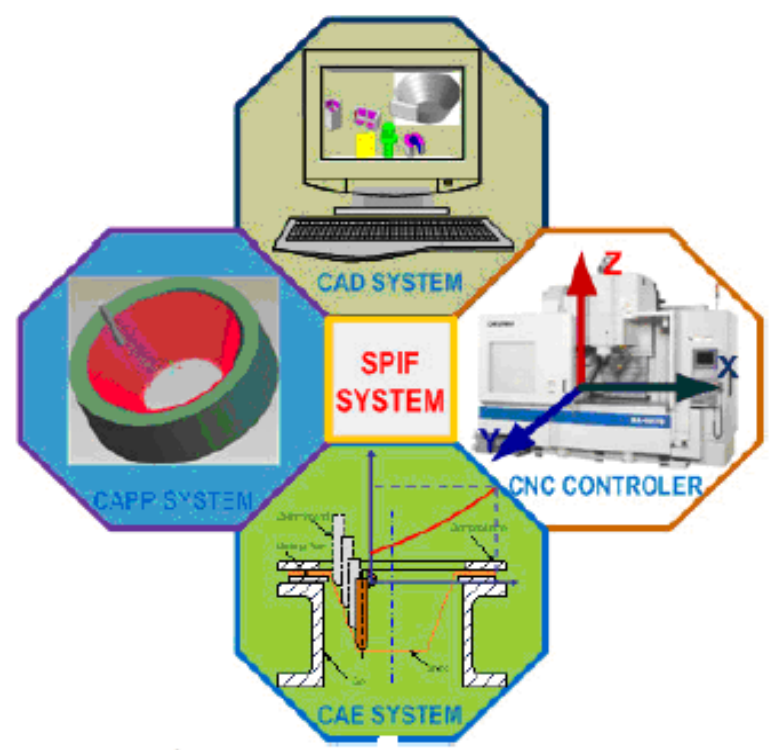

Fig.3. Basic contents of ISF process

The processing has following steps

1/ Part design and 3D modeling: parts are designed with geometry shape depending on customer's demand. Part-modeling is using CAD / CAM integrated specialized software as Pro / E, CATIA, Mastercam, Cimatron or design software Acad, Inventor, Solidwork ... then import to CAM software to machining simulated.

2) CNC machine programing: there are two ways: 1) Directly programming on the CNC machine by the commander integrated. 2) Create G-code first with simulating on computer before exporting to CNC machine. The latter way is safer since it allows to eliminate mistakes and avoids machinery damage or unqualified products.

3/ Machining: in this step, product is gradually formed due to toolpath created for forming tool and it follows product boundary until the last toolpath finished.

4/ Finishing: the product is considered to be qualified if its geometry is similar with that of the design model. Therefore it is necessary to check the product dimension when the process has finished. If large difference exists, the design model will be adjusted.

\section{SAMPLE PARTS MACHINING}

\subsection{Motorcycle box cover machining}

Part features:

- Part is in the industrial-product group.

- There are many contour transitions but it has simple boundary overall.

- High value of slope, little changing in forming area. 


\section{Product requirement:}

- Since being the industrial product, the demand on aesthetic is not strictly. Surface is not necessary to be in very good quality and so is the accuracy.

- The final product is not damaged or twisted.

- There is not the over-deformities effect at the radius transition contour.

CAD model of the product

- 2D drawing of the motorcycle box cover, fig. 4 .
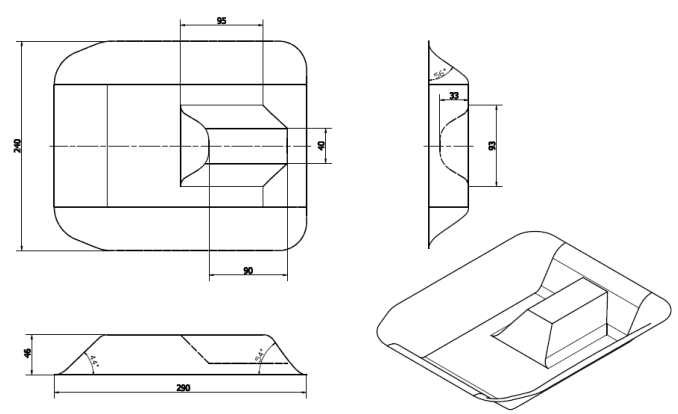

Fig.4. 2D drawing of the box cover product

3D model part made by Inventor software, fig.5.

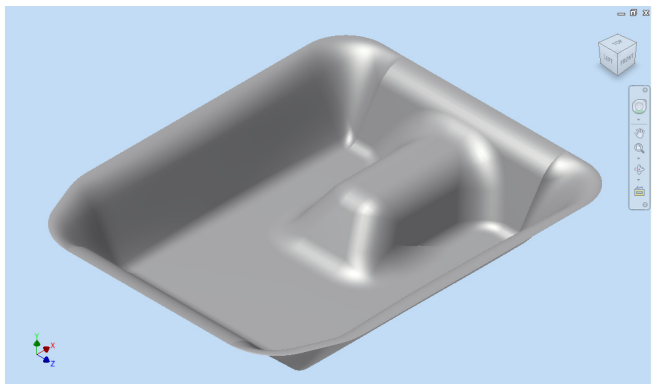

Fig.5. 3D model product by Inventor

CAM model: used for simulating the toolpath. It created by ProEngineer software, (fig.6).
There are two steps for this process:

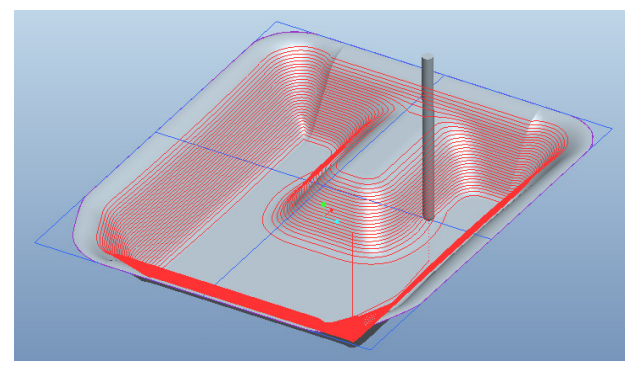

Fig.6. CAM model of the cover box

Milling the supporter for TPIF process:

\section{a) Rough milling}

- Feed rate $\mathrm{f}=1500 \mathrm{~mm} / \mathrm{min}$

- Step depth $\Delta \mathrm{z}=2 \mathrm{~mm}$

- Cutting tool: End mill tool $\varnothing 16$

- Spindle speed $\mathrm{n}=1000 \mathrm{rpm}$

\section{b) Finish Milling}

- Feed rate $\mathrm{f}=1500 \mathrm{~mm} / \mathrm{min}$

- Step depth $\Delta \mathrm{z}=0.3 \mathrm{~mm}$

- Cutting tool : finish end mill tool Ø6

- Spindle speed $\mathrm{n}=1000 \mathrm{rpm}$

\section{Product forming}

This model has the forming angle $\alpha$ from $44^{\circ}$ to $56^{\circ}$. With the dimension shown on $2 \mathrm{D}$ drawing and base on the result of experiment research on maximum forming angle, these parameters of TPIF process on PVC plastic sheet is set as follow:

- Feed rate $\mathrm{f}=2500 \mathrm{~mm} / \mathrm{min}$

- Tool step depth $\Delta \mathrm{z}=1.2 \mathrm{~mm}$

- Forming tool: tool with spheral tip, diameter $\mathrm{d}=6$

- Spindle speed: $\mathrm{n}=1000 \mathrm{rpm}$ 
- Forming temperature: $30 \mathrm{oC}$

\section{Preparation for machine}

- PVC plastic sheet: 350x350x2

- PP plastic workpiece: $300 \times 250 \times 50$

- Fix the PP plastic workpiece onto TPIF fixture

- Set the original position for $\mathrm{x}, \mathrm{y}, \mathrm{z}$ direction on CNC machine. $\mathrm{X}, \mathrm{Y}$ origin is in the middle of workpiece and $\mathrm{Z}$ origin is on the workpiece top surface.

- $\quad$ Milling the plastic supporter, fig.7

- Insert PVC sheet between the upper and lower clamping plate. Set z origin again at top surface of PVC sheet.

- Then forming PVC sheet by ISF technology

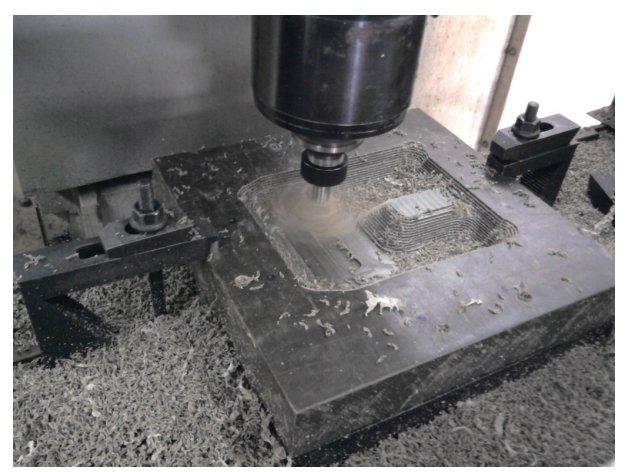

Fig.7. Plastic supporter is milled on CNC machine

Product review: Motorcycle cover box product after finishing the TPIF process, fig. 8 .

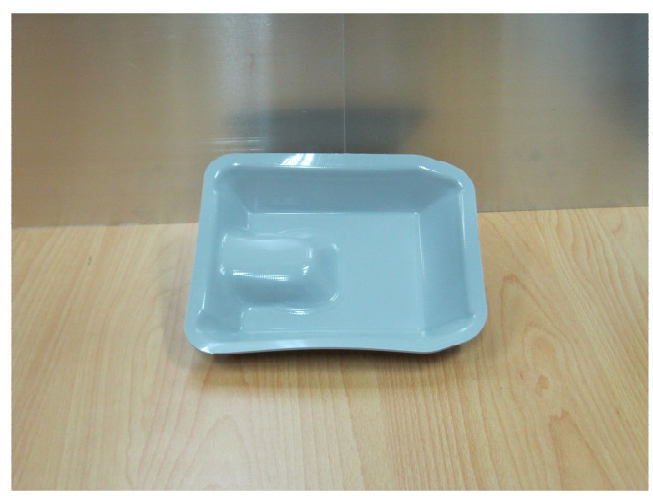

Fig.8. Final product of motorcycle box cover after TPIF process

- $\quad$ There is no damaged surface.

- The geometry of transition contours is clear and not distorted.

\subsection{Headlight machining}

\section{Part features}

- Part is in the industrial-product group.

- Simple cone contour, symmetry axis.

- High value of slope, deep and wide forming area.

\section{Product requirement}

- $\quad$ Not high demand on aesthetics, accuracy and surface quality.

- Final product is not damaged as local distortion.

\section{Product CAD model}

- 2D drawing of the headlight product, fig.9. 


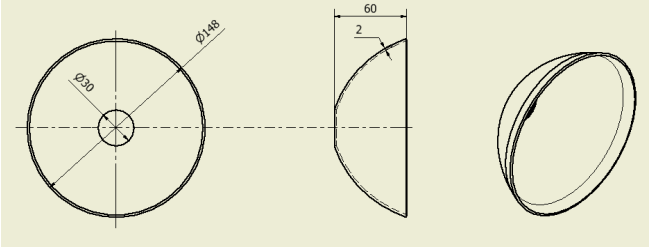

Fig.9. 2D model of the headlight

- 3D model of the headlight is created on Inventor software, fig. 10 .

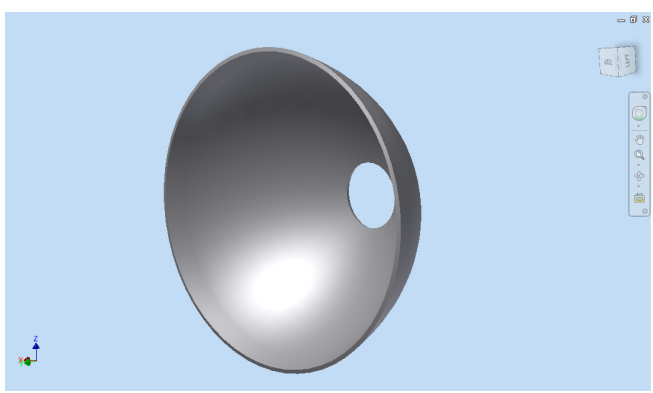

Fig.10. 3D model of the headlight

CAM model: is used for simulating the toothpath of headlight part on ProEngineer software, Fig.11.

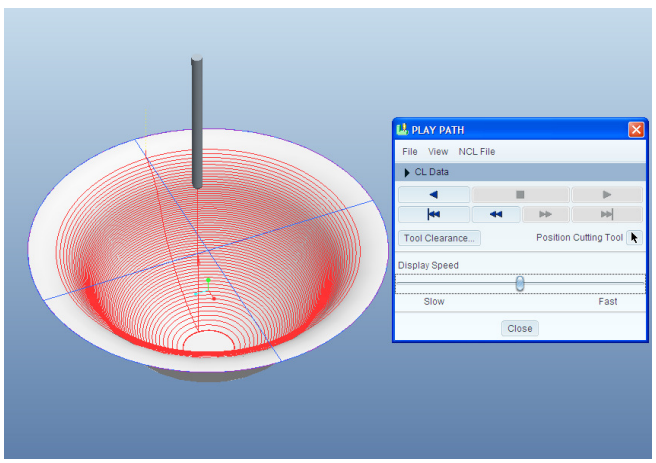

Fig.11. CAM model of the headlight

On this product, there is only one step to deform the sheet blank by SPIF process using simple SPIF fixture.

Headlight model has the maximum forming angle $\alpha_{\max }$ is about 60 degrees and has the curved boundary. With all these features and base on the result of experiment research on maximum forming angle, these parameters of SPIF process on PVC plastic sheet is set as follow:

- $\quad$ Feed rate $\mathrm{f}=2500 \mathrm{~mm} / \mathrm{min}$

- $\quad$ Tool step depth $\Delta \mathrm{z}=1.2 \mathrm{~mm}$

- Forming tool: tool with spheral tip, diameter $\mathrm{d}=6 \mathrm{~mm}$

- $\quad$ Spindle speed $\mathrm{n}=1000 \mathrm{rpm}$

- Forming temperature: $30^{\circ} \mathrm{C}$

\section{Machining preparation:}

- PVC plastic sheet: 280x280x2

- Set the original position for $\mathrm{x}, \mathrm{y}, \mathrm{z}$ direction on CNC machine. $\mathrm{X}, \mathrm{Y}$ origin is in the middle of the lower supporter plate which has a $200 \mathrm{~mm}$ diameter hole below

- Insert PVC sheet between the upper and lower clamping plate. Set z origin again at top surface of PVC sheet.

- Moving up the tool to create a distance of $20 \mathrm{~mm}$ between tool tip angle PVC top surface.

Product review: headlight product after processing by SPIF technology, fig. 12 . 


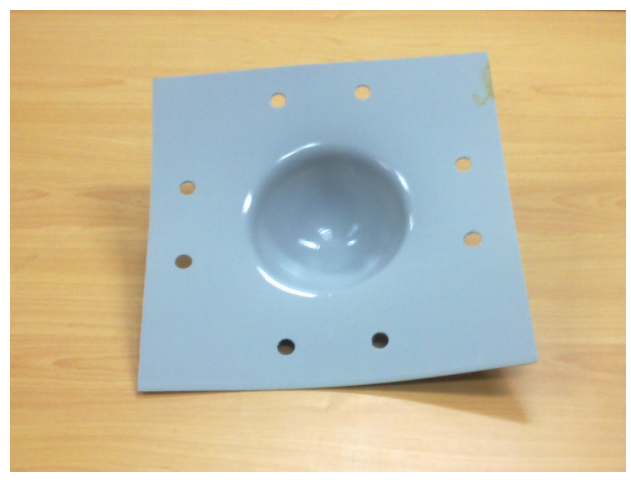

Fig.12. Headlight product after processing by SPIF

- The plastic headlight has been formed successfully without any distortion and damage on product surface.

- Shape of the product is clear and not over-deformation

\section{EVALUATING ECONOMIC EFFICIENCY}

Evaluation of economic efficiency is to provide an understanding the application of the ISF technology in specific cases. It is consider that if ISF technology can be used in rapid prototyping, single production, small batch or mass production. To answer this question, it is necessary to compare ISF process with another processing - the plastic injection method. There does not include the cost of investment in machinery, energy, machine rental, profit.
According to [7] [8], the cost of a product when processing by ISF and by plastic injection menthod includes:

\section{By ISF technology}

- Die cost (fixture, simulation + programing, plastic supporter): depend on each product.

- PVC plastic sheet: 30,000 VND

- Forming time: depended on each product, presented in the follow table.

- Labor costs: 40,000 VND/hour

By the plastic injection method

- Die cost (design, workpiece, manufacturing): depends on each product.

- PVC plastic seeds: 30,000 VND

- Cycle of product injection: depend on each product, presented in the follow table.

- Labor costs: 40,000 VND/hour

4.1. Cost calculation for motorcycle box cover product

Form the demands of dimension and geometry of the part, the table of cost prediction can be calculated (table 1) for two method :

Table 1. Table of cost prediction for motorcycle box cover product

\begin{tabular}{|l|l|l|c|}
\hline \multicolumn{1}{|c|}{ Cost } & Unit & ISF (VND) & $\begin{array}{c}\text { Plastic Injection } \\
(\text { VND) }\end{array}$ \\
\hline Die cost & VND & 5.500 .000 & 34.500 .000 \\
\hline Machining time & hour & 1,25 & $0,006944(25 \mathrm{~s})$ \\
& & $(75 \mathrm{~min})$ & \\
\hline Cost for PVC plastic & VND & 30.000 & 30.000 \\
\hline
\end{tabular}




\begin{tabular}{|l|l|l|l|}
\hline Labor costs & VND & 50.000 & 278 \\
\hline Total cost per product & VND & $\mathbf{5 . 5 8 0 . 0 0 0}$ & $\mathbf{3 4 . 5 3 0 . 2 7 8}$ \\
\hline
\end{tabular}

To evaluate the economic efficiency estimate the cost of one product when brought by the ISF process when compared processing the large number of products, table with plastic injection process, it is necessary to

2 .

Table 2. Table of cost per product when processing with many products

\begin{tabular}{|c|c|c|}
\hline \multirow{2}{*}{ Number of product } & \multicolumn{2}{|c|}{ TECHNOLOGY USED } \\
\cline { 2 - 3 } & ISF & PLASTIC INJECTION \\
\hline 1 & 5,580 & 34,530 \\
\hline 10 & 630 & 3,480 \\
\hline 20 & 355 & 1,755 \\
\hline 50 & 190 & 720 \\
\hline 100 & 135 & 375 \\
\hline 200 & 108 & 203 \\
\hline 500 & 91 & 99 \\
\hline 1000 & 86 & 65 \\
\hline 1500 & 84 & 53 \\
\hline 2000 & 83 & 48 \\
\hline
\end{tabular}

Figure 13 presents the chart of manufacturing cost per product in comparison between two technologies.

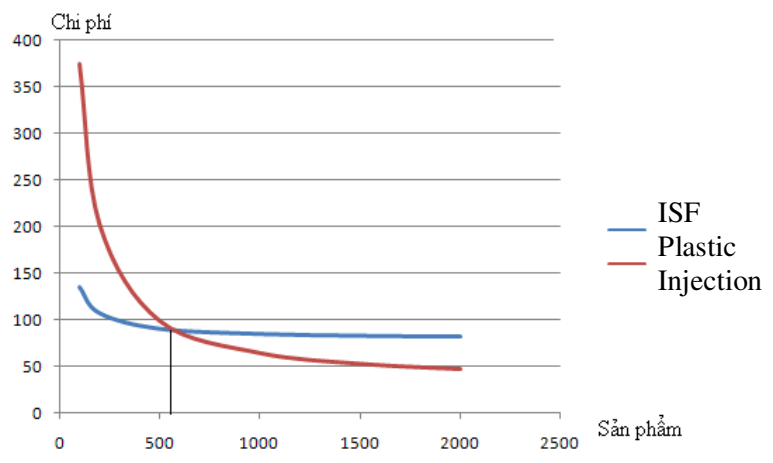

Fig.13.Chart of manufacturing cost in comparison between ISF and plastic injection method 
4.2. Cost calculation for headlight product

Form the demand of dimension and geometry of the part, the table of cost prediction can be calculated (table 3) for two methods:

Table.3. Table of cost prediction for one headlight product

\begin{tabular}{|l|l|l|l|}
\hline \multicolumn{1}{|c|}{ Cost } & \multicolumn{1}{|c|}{ Unit } & \multicolumn{1}{c|}{ ISF (VND) } & \multicolumn{1}{c|}{$\begin{array}{c}\text { PLASTIC INJECTION } \\
(\text { VND) }\end{array}$} \\
\hline Die cost & VND & 4.800 .000 & 23.000 .000 \\
\hline Machining time & Hour & $0,75(45 \mathrm{~min})$ & $0,002777(10 \mathrm{~s})$ \\
\hline Plastic cost & VND & 30.000 & 30.000 \\
\hline Labor costs & VND & 30.000 & 111 \\
\hline Total cost per product & VND & $\mathbf{4 . 8 6 0 . 0 0 0}$ & $\mathbf{2 3 . 0 3 0 . 1 1 1}$ \\
\hline
\end{tabular}

To evaluate the economic efficiency brought by the ISF process when compared with plastic injection process, it is necessary to estimate the cost of one product when processing the large number of products, table 4.

Table.4. Table of cost per headlight product when processing with many products

\begin{tabular}{|c|c|c|}
\hline \multirow{2}{*}{$\begin{array}{c}|c| \\
\text { PUMBER OF }\end{array}$} & \multicolumn{2}{|c|}{ TECHNOLOGY USED } \\
\cline { 2 - 3 } & ISF & PLASTIC INJECTION \\
\hline 1 & 4,860 & 23,030 \\
\hline 10 & 540 & 2,330 \\
\hline 20 & 300 & 1,180 \\
\hline 50 & 156 & 490 \\
\hline 100 & 108 & 260 \\
\hline 200 & 84 & 145 \\
\hline 500 & 70 & 76 \\
\hline 1000 & 65 & 53 \\
\hline 1500 & 63 & 45 \\
\hline 2000 & 62 & 42 \\
\hline
\end{tabular}


Figure14 presents the chart of manufacturing cost per headlight product in comparison between two technologies.

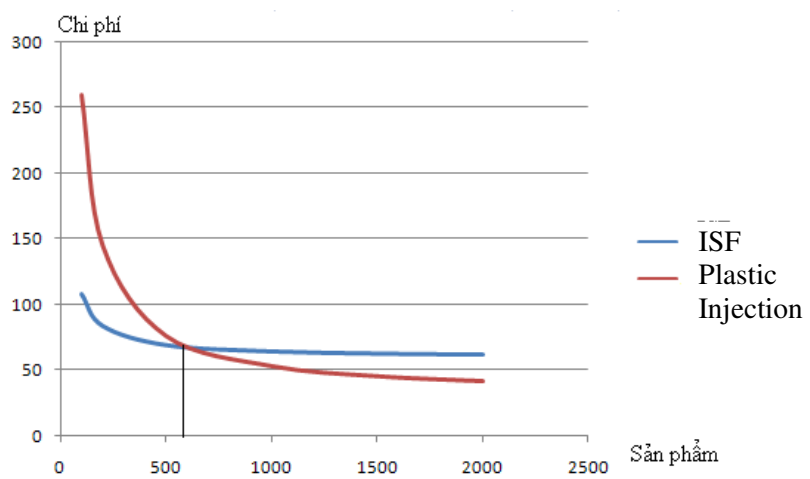

Fig.14. Chart of manufacturing cost of headlight product in comparison between ISF and plastic injection method

Observing the cost curve in comparison between ISF technology and plastic injection method, we can find that the two curves intersect at around 550 products. This shows that the application of the ISF process is effective in cases processing under 550 products. If the more products is manufactering, this process does not bring high economic efficiency.

\section{CONCLUSION}

For ISF process the original cost is lower because of simple fixture while the other method has higher cost at the first step since high cost for die and it also takes times to manufacturing the die.

ISF technology is suitable only for rapid prototype, single batch prodution, small and medium batch production (below 550 products). In mass production, ISF technology does not have fully economic efficiency in comparison with the other plastic forming method.

\section{Trang 24}




\title{
NGHIÊN CƯU ÚNG DỤNG CÔNG NGHệ TẠO HİNH ISF TRÊN TẤM NHỰA PVC GIA CÔNG MộT SỐ SẢN PHẨM DÂN DỤNG
}

\author{
Nguyễn Văn Nang ${ }^{(1)}$, Nguyễn Thanh Nam ${ }^{(1)}$, Lê Khánh Điền ${ }^{(2)}$, Nguyễn Thiên Bình ${ }^{(1)}$ \\ (1) Phòng thí nghiệm Điều khiển số và Kỹ thuật hệ thống \\ (2) Trường Đại học Bách Khoa, ĐHQG-HCM
}

TÓM TÁT: Đối với sản phẩm nhựa, do nhu cầu thị trương thuờng xuyên thay đổi hình dáng, mẫu mã nên cần tạo ra sản phẩm mẫu duới hình thức đơn chiếc hay loạt nhỏ, yêu cầu thời gian qui trình sản xuất ngắn, chi phí gia công thấp, quá trình vận hành đơn giản mà vẫn đảm bảo các yêu cầu kỹ thuật. Bài báo trình bày một nghiên cứu ưng dụng qui trình ISF để gia công tạo hình sản phẩm mâu hay các sản phẩm loạt nhỏ tù các tấm nhựa PVC. So sánh hiệu quả kinh tế mang lại giũa công nghệ tạo hình ISF và các kỹ thuật gia công nhựa thông thuờng.

Keyword: Ứng dụng công nghệ ISF, Quy trình ISF, Chế tạo sản phẩm dân dụng tù̀ nhụa PVC.

\section{REFERENCES}

[1]. Kathryn Jackson, Julian Allwood,The mechanics of incremental sheet forming, Department of Engineering, University of Cambridge, 16 Mill Lane, Cambridge CB2 1RX, UK (2007).

[2]. Pohlak, M.; Küttner, R.; Majak, J.; Karjust, K. \& Sutt, A., Simulation of incremental eorming of sheet metal products - industrial engineering innovation as competitive edge for sme, Tallinn, Estonia (2004).

[3]. Pohlak, M.; Küttner, R.; Majak, J.; Karjust, K. \& Sutt, A., Simulation of incremental eorming of sheet metal products - industrial engineering innovation as competitive edge for sme, Tallinn, Estonia (2004).
[4]. Martins, P.A.F.'; Bay N. (1) ${ }^{\mathrm{b}, *}$; Skjoedt ${ }^{\mathrm{b}}, \mathrm{M}$.; Silva, M.B. ${ }^{\mathrm{a}}$,Theory of single point incremental forming, ${ }^{\mathrm{a}} \mathrm{IDMEC}$, Instituto Superior Tecnico, TULisbon, Portugal; ${ }^{\mathrm{b}}$ Department of Mechanical Engineering, Technical University of Denmark, Denmark(2008).

[5]. Emmens, W.C. ${ }^{\mathrm{a}, *}$; Sebastiani ${ }^{\mathrm{b}}, \mathrm{G} . ; \mathrm{Van}$ den Boogaard,A.H. ${ }^{\mathrm{c}}$, The technology of Incremental Sheet Forming-A brief review of the history, ${ }^{\mathrm{a}} \mathrm{CORUS} \mathrm{RD} \& \mathrm{~T}$, PO Box 10.000, 1970 CA IJmuiden, The Netherlands; ${ }^{b}$ Institute of Forming Technology and Lightweight Construction (IUL), Technische Universität Dortmund, Baroper Strasse 301, 44227 Dortmund, Germany; ' University of Twente, PO Box 217, 7500 AE Enschede, The Netherlands (2010). 
[6]. Le,V. S. ${ }^{1^{*}}$; Nguyen,T. N. ${ }^{2}$;Le, K. D. ${ }^{2}$; Ghiotti ${ }^{1}$,A. ;Ucchetta,G. ${ }^{1}$,Incremental sheet forming of glass mat thermoplastic - ${ }^{1}$ DIMEG - University of Padova - Via Venezia, 1, 35131 Padova, Italy; ${ }^{2}$ Department of Machine Design HoChiMinh City University of Technology, Viet Nam.
[7]. Pedro Pablo Rrodriguez - Incremental sheet forming Industrial applications International seminar on Novel sheet metal forming technologies, Finland, (2006). 